\title{
KONSENTRASI DAERAH PERHOTELAN DI KAWASAN DANAU TOBA
}

\author{
Syahrial ${ }^{1)}$, Lincolin Arsyad ${ }^{2)}$ \\ ${ }^{1}$ Perbankan Syariah, Sekolah Tinggi Agama Islam Negeri Mandailing Natal, Indonesia \\ syahrial@stain-madina.ac.id \\ ${ }^{2}$ Departemen Ilmu Ekonomi, Fakultas Ekonomi dan Bisnis, Universitas Gadjah Mada, Indonesia \\ lincolinarsyad@ugm.ac.id
}

\begin{abstract}
In today's modern world, the number of hotels and other accommodations is increasing in Indonesia in general and in the province of North Sumatra in particular. The same situation also occurs in the Toba lake region which covers seven districts surrounding Toba lake with a number of hotels that vary in each district. This study aims to analyze the possibility of classification of the hospitality area concentration in the Toba lake region and analyze the shift in the classification of the hospitality area concentration in the Toba lake region. Panel data used will be analyzed using the method of classification analysis of the hospitality area concentration in the Toba lake region. Then it will be assisted by geographic information system analysis as a visualization tool for maps of hospitality areas in the Toba lake region. This research shows that the Toba lake region consists of two classifications, namely: the classification of the main area of hospitality that cover three district and the non-concentration classification of hospitality areas that includes four districts. During the study period, the shift in the classification of the hospitality area concentration were not found in the Toba lake region.
\end{abstract}

Keywords : Geographic Information System ${ }^{1}$, Hospitality Area Concentration ${ }^{2}$

\section{PENDAHULUAN}

Struktur ekonomi setiap negara akan berubah semakin berkembangnya zaman, mulai dari sektor primer berupa pertanian dan pertambangan, sektor sekunder berupa industri manufaktur, dan berakhir pada sektor tersier berupa jasa dan pariwisata. Akhir-akhir ini Indonesia menunjukkan 10 Bali Baru sebagai prioritas dalam sektor pariwisata. Pemerintah Indonesia yang diwakili menteri pariwisata Arief Yahya meluncurkan 10 Bali Baru tepat pada Konferensi Tingkat Tinggi Indian Ocean Rim Association 2017 (KTT IORA) yang mencakup danau Toba, Tanjung Klayang, Tanjung Lesung, Kepulauan Seribu, Borobudur, Bromo, Mandalika, Labuan Bajo, Wakatobi, dan Morotai (Viva.co.id, 2017).

Letak administrasi dan geografis masing-masing 10 Bali Baru tersebut terletak di daerah yang berbeda-beda. Danau Toba berada di provinsi Sumatera Utara dan mencakup tujuh kabupaten yaitu kabupaten Simalungun, kabupaten Toba Samosir, kabupaten Samosir, 
kabupaten Tapanuli Utara, kabupaten Humbang Hasundutan, kabupaten Dairi, dan kabupaten Karo. Tanjung Kelayang berada di kabupaten Blitung provinsi Bangka Blitung. Tanjung Lesung berada di kabupaten Pandeglangan provinsi Banten. Kepulauan Seribu berada di Daerah Khusus Ibukota (DKI) Jakarta. Borobudur berada di kabupaten Magelang provinsi Jawa Tengah. Bromo berada di provinsi Jawa Timur yang mencakup kabupaten Pasuruan, kabupaten Malang, dan kabupaten Probolinggo. Mandalika berada di kota Mataram provinsi Nusa Tenggara Barat (NTB). Labuan Bajo berada di kabupaten Manggarai Barat provinsi Nusa Tenggara Timur (NTT). Wakatobi berada di provinsi Sulawesi Tengah. Kemudian yang terakhir adalah Morotai yang dikenal dengan nama asli kabupaten Pulau Morotai provinsi Maluku.

Ketika KTT IORA 2017 berlangsung, menteri pariwisata menegaskan bahwa Indonesia akan meningtkatkan target kunjungan wisatawan mancanegara (wisman) pada tahun 2019 menjadi 20 juta wisman (VIVA.co.id, 2017), sehingga sejumlah investor akan dibutuhkan untuk menunjang pariwisata Indonesia seperti hotel dan akomodasi lainnya. Danau Toba adalah satu dari 10 Bali Baru yang sangat unik secara letak lokasi/geografis dibandingkan sembilan tempat wisata lainnya karena danau Toba dikelilingi oleh tujuh kabupaten sedangkan yang lainnya hanya satu sampai tiga administrasi daerah kabupaten/kota saja. Ketujuh kabupaten ini masuk dalam kawasan danau Toba sebagaimana disebutkan Kementerian Pekerjaan Umum dan Perumahan Rakyat (Kementerian PUPR) dalam Profil Kawasan danau Toba (2016).

Pada tiga tahun terakhir ini, kuantitas hotel dan akomodasi lainnya di provinsi Sumatera Utara mengalami peningkatan yaitu 789 unit tahun 2013 meningkat 823 unit tahun 2014 dan 829 unit tahun 2015 (BPS Sumatera Utara, 2017). Kondisi yang sama terjadi di kawasan danau Toba yaitu 230 unit tahun 2013 meningkat 257 unit tahun 2014 dan 269 unit tahun 2015 (BPS Sumatera Utara, 2017). Meskipun demikian perlu untuk diteliti lebih lanjut lagi terkait lokasi konsentrasi utama daerah perhotelan di kawasan danau Toba berada di daerah/kabupaten mana. Disebut demikian karena pada tahun 2015 jumlah hotel dan akomodasi lainnya dimasing-masing kabupaten di kawasan danau Toba sangat bervariasi. 
Paragraf di atas mengungkapkan benar adanya bahwa potensi besar wisata danau Toba didukung oleh peningkatan kuantitas hotel dan akomodasi lainnya di kawasan danau Toba pada tiga tahun terakhir. Akan tetapi sangat disanyangkan, peningkatan kuantitas hotel dan akomodasi lainnya tersebut masih diliputi oleh tingginya kesenjangan kuantitas hotel dan akomodasi lainnya di masing-masing kabupaten yang mengelilingi danau Toba, padahal salah satu pendukung utama industri pariwisata adalah hotel dan akomodasi lainnya. Pada tahun 2016, perhotelan terkonsentrasi di kabupaten Samosir dengan dengan perbandingan yang sangat fantastis yakni mencapai sepuluh kali lipat jumlah hotel dan akomodasi lainnya di kabupaten Humbang Hasundutan (BPS Sumatera Utara, 2017).

Berdasarkan pada uraian di atas, maka perlu mengklasifikasikan di daerah mana letak konsentrasi/lokasi utama daerah perhotelan di kawasan danau Toba. Kemudian perlu dianalisis kemungkinan terjadinya pergeseran letak klasifikasi daerah perhotelan di kawasan danau Toba. Semua ini dilakukan karena tidak tertutup kemungkinan bahwa seiring berjalanya waktu jumlah hotel dan akomodasi lainnya di kawasan danau Toba selalu mengalami fluktuatif. Tentu saja hal serupa dialami oleh sedikit banyaknya jumlah tenaga kerja yang diserap oleh sektor hotel dan akomodasi lainnya tersebut. Singkatnya, penelitian ini bertujuan menganalisis kemungkinan terjadinya klasifikasi konsentrasi daerah perhotelan di kawasan danau Toba dan menganalisis pergeseran klasifikasi konsentrasi daerah perhotelan di kawasan danau Toba

\section{TINJAUAN PUSTAKA}

\section{Hotel dan Akomodasi Lainnya}

Sektor pariwisata selaku sektor tersier sangat mempengaruhi pendapatan suatu daerah, begitu juga denga devisa suatu negara. Sebuah kewajaranan bilamana sektor ini diperhitungkan karena sektor tersier merupakan sektor puncak dari beberapa sektor ekonomi yang ada. Besarnya pengaruh sektor pariwita membuat setiap negara bahkan masing-masing daerah seolah-olah berkompetisi dalam menarik hati wisatawan mancanegara (wisman) maupun wisatawan nusantara (lokal) untuk mengunjungi tempat mereka. Masing-masing daerah menyadari bahwa sektor pariwisata akan memunculkan multiplier effect dari produk barang dan jasa yaitu seperti menstimulus jasa transportasi, akomodasi, kuliner, telekomunikasi, hiburan, kesehatan, salon, produk kerajinan tangan, dan lain-lain. 
Hospitaliti adalah salah saru faktor penentu keberhasilan maupun kegagalan bisnis pariwisata sehingga dalam mengakomodir wisatawan diperlukan penyediaan hospitaliti yang terbaik. Hospitaliti berkaitan erat dengan penyediaan segala sesuatu yang dibutuhkan termasuk fasilitas selama mengunjungi lokasi wisata dengan maksud untuk bersenangsenang. Satu diantara fasislitas hospitaliti paling menonjol adalah jasa pehotelan atau akomodasi yang tersedia di lokasi wisata tersebut.

Dalam pandangan dunia pariwisata, bisnis akomodasi adalah suatu bentuk bisnis yang bergerak dalam penyediaan berupa akomodasi selama jangka waktu yang relatif singkat kepada pengunjung dan pelancong lainnya pada suatu lokasi tertentu (BPS, 2017). Dalam hal ini, bisnis penyediaan akomodasi tersebut bisa berbentuk penyediaan fasilitas akomodasi saja maupun berbentuk fasilitas akomodasi yang dilengkapi oleh fasilitas lainnya seperti makanan dan minuman.

\section{Penduduk dan Ketenagakerjaan}

Dalam BPS (2017) dijelaskan bahwa penduduk adalah semua orang yang berdomisili di wilayah geografis Republik Indonesia selama enam bulan atau lebih dan atau mereka yang berdomisili kurang dari enam bulan tetapi bertujuan untuk menetap. Seiring berjalannya waktu, jumlah penduduk pun semakin banyak yang berimbas pada meningkatnya penawaran tenaga kerja setiap tahun. Tenaga kerja laki-laki maupun tenaga kerja wanita yang sudah berumur lima belas tahun ke atas sudah masuk dalam status angkatan kerja di Indonesia (BPS, 2017)

Menurut Kuncoro (2015) bekerja adalah seseorang yang melakukan aktivitas ekonomi dengan durasi setidaknya satu jam dan berkelanjutan terus menerus selama satu minggu yang lalu demi memperoleh penghasilan, baik untuk diri sendiri maupun untuk membantu penghasilan orang tua. Seseorang yang sedang tidak bekerja seminggu yang lalu untuk sementara waktu karena suatu alasan seperti sakit dan cuti pun masih dikategorikan dalam kegiatan bekerja, dengan syarat orang tersebut sudah memiliki pekerjaan sebelumnya. Pada kasus ketenagakerjaan, lapangan pekerjaan yang tersedia tidak selalu mampu menyerap semua tenaga kerja karena kondisi ekonomi suatu daerah yang berbeda-beda satu sama lainnya. Oleh karenanya Kuncoro (2015) menyebutkan bahwa ada beberapa indikator yang mampu memotret kondisi ketenagakerjaan suatu negara ataupun daerah. 
Indikator tersebut adalah tingkat partisipasi angkatan kerja (TPAK), angka penyerapan angkatan kerja (employment rate), dan tingkat pengangguran terbuka (TPT).

Hotel dan akomodasi lainnya akan mampu menyerap tenaga kerja sebanyak mungkin bilamana jumlah perhotelan semakin banyak. Sebaliknya, jumlah perhotelan yang sedikit hanya bisa menyerap tenaga kerja yang sedikit pula. Sedikit banyaknya tenaga kerja yang terserap oleh perhotelan dikarenakan produk dari perhotelan adalah jasa yang mana notabenya langsung pelayanan dari tenaga kerja itu sendiri.

\section{Teori Lokasi}

Teori lokasi sangat erat kaitannya dengan penentuan lokasi, baik berupa suatu usaha oleh swasta, pemukiman oleh masyarakat, maupun pendirian barang publik oleh pemerintah. Jika dikerucutkan pada dunia bisnis, teori lokasi ini akan mampu membantu pembuat keputusan dalam mewujudkan efisiensi untuk produksi dan pemasaran seperti terwujudnya ongkos angkut yang relatif lebih murah. Tujuan utama perusahaan adalah profit sehingga perusahaan akan memaksimalisasi profit melalui optimalisasi output atau minimalisasi input (biaya). Dengan demikian perlu untuk melakukan perbandingan biaya yang dikeluarkan.

Indikator kemudahan dalam menjangkau suatu lokasi aktivitas ekonomi dengan berjalan kaki maupun menggunakan transportasi adalah berkaitan dengan aksebilitas. Muta'ali (2015) juga mengemukakan bahwa kemudahan dalam perpindahan, jarak tempuh, waktu tempuh, dan biaya yang ditanggung merupakan indikator aksebilitas. Transportasi selaku alat mobilisasi faktor produksi dalam aktivitas ekonomi akan bermuara pada besar kecilnya ongkos angkut dalam aktivitas tersebut. Ongkos angkut merupakan hal utama untuk dipertimbangkan karena akan berpengaruh pada efisiensi ekonomi. Jika ongkos angkut besar maka akan memicu biaya yang lebih tinggi. Jika ongkos angkut kecil maka akan memicu biaya yang lebih rendah. Simpulnya adalah biaya yang rendah lebih dipilih daripada biaya yang tinggi pada output barang/jasa yang sama.

Seorang pelaku bisnis wajib mengetahui seberapa besar biaya yang ditimbulkan apabila berencana mendirikan suatu usaha di lokasi tertentu. Pertimbangan yang harus diputuskan adalah mendirikan usaha dekat dengan bahan baku (input) atau malah dekat dengan pasar 
demi tercapainya biaya paling rendah. Orang rasional tentu akan memilih lokasi yang menimbulkan biaya produksi dan biaya transportasi yang rendah.

Seorang investor maupun pengembang yang ingin menentukan lokasi perhotelan, bisa saja mengaplikasikan teori lokasi sebagaimana sudah dibahas pada alinea sebelumnya yakni dengan mempertimbangkan jarak hotel ke lokasi input dan jarak hotel ke pasar. Biasanya semakin jauh jarak maka semakin tinggi ongkos angkut, dan semakin dekat jarak semakin rendah ongkos angkut. Lokasi input bisa saja berupa bandara udara, terminal, stasiun, dan dermaga/pelabuhan yang merupakan pintu keluar masuk pengunjung. Kemudian pasar yang dimaksud adalah lokasi wisata sebagai tujuan dari pengunjung/pelancong/wisatawan.

Pada intinya, prinsip dasar lokasi industri bisa saja diaplikasikan pada penentuan lokasi penyediaan jasa seperti: (1) akses ke sumber input, (2) akses ke pasar, (3) skala produksi dan ekonomi aglomerasi. Prinsip kedekatan penyediaan jasa pada pasar adalah bahwa jasa yang disuguhkan lebih bersifat langsung (direct) kepada konsumen. Prinsip ini berbeda dengan penyediaan produk barang yang bisa secara langsung maupun tidak langsung yakni distok dalam jangka waktu tertentu dan kemudian dimanfaatkan di masa mendatang. Beberapa contoh bisnis penyedia jasa adalah jasa bimbingan belajar, salon, restoran, jasa cuci pakaian, jasa reparasi, rumah sakit, hotel, dan lain-lain. Dari macam-macam contoh bisnis penyediaan jasa yang ada, bisnis perhotelan termasuk jasa yang sangat penting dalam dunia pariwisata.

\section{METODE PENELITIAN}

Penelitian ini memakai data kuantitatif (berbentuk numerik/angka) yang terdiri dari data jumlah unit hotel dan akomodasi lainnya dan jumlah tenaga kerja yang diserap oleh hotel dan akomodasi lainnya tersebut. Sebagai pelengkap, data geospasial juga akan digunakan dalam penelitian ini. Data geospasial yang digunakan adalah data geospasial vektor yakni berupa data yang disimpan dalam susunan koordinat pada peta digital berbentuk shapefile (shp) (Raharjo dan Ikhsan, 2015). Kedua macam data merupakan data sekunder yang diperoleh dari Badan Pusat Statistik (BPS). Masing-masing data mulai dari periode 20072016 pada tujuh daerah administratif yaitu kabupaten Simalungun, kabupaten Toba Samosir, kabupaten Samosir, kabupaten Tapanuli Utara, kabupaten Humbang Hasundutan, kabupaten Dairi, dan kabupaten Karo. Dapat disimpulkan bahwa data yang digunakan 
adalah data panel yakni gabungan data runtut waktu (time series) dan data silang tempat (cross section).

Beberapa tahapan dalam penelitian ini adalah: (1) mengklasifikasikan konsentrasi daerah perhotelan. Variabel pembentuk klasifikasi konsentrasi daerah perhotelan tersebut adalah jumlah unit hotel dan akomodasi lainnya dan jumlah tenaga kerja yang diserap hotel dan akomodasi lainnya tersebut; (2) memvisualisasikan daerah penelitian melalui Geographic Information System (GIS). Melalui tahapan ini akan terlihat yang termasuk konsentrasi daerah perhotelan atau yang bukan lokasi konsentrasi daerah perhotelan dalam bentuk peta daerah penelitan; (3) tahap terakhir adalah menganalisis kemungkinan terjadinya pergeseran klasifikasi konsentrasi daerah perhotelan di kawasan danau Toba selama periode penelitian.

\section{Analisis Klasifikasi Konsentrasi Daerah Perhotelan}

Analisis yang dipakai ini adalah hasil modifikasi analisis tipologi Klassen atau sering disebut tipologi daerah sebagaimana yang ditunjukkan pada Tabel 1 di bawah ini.

Tabel 1. Klasifikasi Konsentrasi Daerah Perhotelan

\begin{tabular}{|c|c|c|c|}
\hline \multicolumn{2}{|c|}{} & \multicolumn{2}{|c|}{$\begin{array}{c}\text { Jumlah Tenaga Kerja Hotel dan Akomodasi } \\
\text { Lainnya }\end{array}$} \\
\cline { 2 - 4 } \multicolumn{2}{|c|}{ Variabel } & $\begin{array}{c}\text { Di atas rata-rata } \\
\text { (tinggi) }\end{array}$ & $\begin{array}{c}\text { Di bawah rata-rata } \\
\text { (rendah) }\end{array}$ \\
\hline \multirow{2}{*}{$\begin{array}{c}\text { Jumlah Unit } \\
\text { Hotel dan } \\
\begin{array}{c}\text { Akomodasi } \\
\text { Lainnya }\end{array}\end{array}$} & $\begin{array}{c}\text { Di atas } \\
\text { rata-rata } \\
\text { (tinggi) }\end{array}$ & $\begin{array}{c}\text { Konsentrasi utama } \\
\text { daerah perhotelan }\end{array}$ & $\begin{array}{c}\text { II. } \\
\text { Konsentrasi daerah } \\
\text { produktif menyerap } \\
\text { tenaga kerja }\end{array}$ \\
\cline { 2 - 4 } & $\begin{array}{c}\text { Di bawah } \\
\text { rata-rata } \\
\text { (rendah) }\end{array}$ & $\begin{array}{c}\text { I. } \\
\text { Bukan konsentrasi daerah } \\
\text { perhotelan tapi produktif } \\
\text { menyerap tenaga kerja }\end{array}$ & $\begin{array}{c}\text { Bukan konsentrasi } \\
\text { daerah perhotelan }\end{array}$ \\
\hline
\end{tabular}

Sumber: Sintesis peneliti, 2018

Perbedaan keduanya terletak pada variabel yang dipakai dan penamaan klasifikasi daerahnya. Variabel yang digunakan dalam tipologi Klassen adalah laju pertumbuhan dan pendapatan per kapita (Arsyad, 2016), sementara variabel dalam penelitian ini jumlah unit hotel dan akomodasi lainnya dan jumlah tenaga kerja yang diserap oleh hotel dan 
akomodasi lainnya tersebut. Klasifikasi daerah yang dihasilkan Arsyad (2016) berdasarkan pada klasifikasi Klassen adalah: (I) Daerah makmur, (II) Daerah tertekan dalam proses membangun, (III) Daerah makmur yang sedang menurun, dan (IV) Daerah tertekan. Sementara klasifikasi konsentrasi daerah perhotelan yang ditawarkan dalam penelitian ini adalah sebagaimana Tabel 1 di atas. Klasifikasi I adalah konsentrasi utama daerah perhotelan, yaitu daerah dengan jumlah unit hotel dan akomodasi lainnya dan jumlah tenaga kerja pada hotel dan akomodasi lainnya lebih banyak dibandingkan dengan ratarata jumlah unit hotel dan akomodasi lainnya dan rata-rata jumlah tenaga kerja pada hotel dan akomodasi lainnya di kawasan danau Toba. Klasifikasi II adalah konsentrasi daerah perhotelan tapi tidak produktif menyerap tenaga kerja, yaitu daerah dengan jumlah unit hotel dan akomodasi lainnya lebih banyak dibandingkan dengan rata-rata jumlah unit hotel dan akomodasi lainnya di kawasan danau Toba, namun jumlah tenaga kerja pada hotel dan akomodasi lainnya di daerah tersebut lebih sedikit dibandingkan dengan rata-rata jumlah tenaga kerja pada hotel dan akomodasi lainnya di kawasan danau Toba. Klasifikasi III adalah bukan konsentrasi daerah perhotelan tapi produktif menyerap tenaga kerja, yaitu daerah dengan jumlah unit hotel dan akomodasi lainnya lebih sedikit dibandingkan dengan rata-rata jumlah unit hotel dan akomodasi lainnya di kawasan danau Toba, namun jumlah tenaga kerja pada hotel dan akomodasi lainnya di daerah tersebut lebih banyak dibandingkan dengan rata-rata jumlah tenaga kerja pada hotel dan akomodasi lainnya di kawasan danau Toba. Terakhir klasifikasi IV adalah bukan konsentrasi daerah perhotelan, yaitu daerah dengan jumlah unit hotel dan akomodasi lainnya dan jumlah tenaga kerja pada hotel dan akomodasi lainnya lebih sedikit dibandingkan dengan rata-rata jumlah unit hotel dan akomodasi lainnya dan rata-rata jumlah tenaga kerja pada hotel dan akomodasi lainnya di kawasan danau Toba.

Kemudian scatter plot memakai SPSS 21 dan geographic information system (GIS) memakai ArcMAP 10.1 akan dipakai untuk membantu dalam melakukan analisis konsentrasi daerah perhotelan di kawasan danau Toba. Prinsip scatter plot adalah memperlihatkan atau menunjukkan pengelompokan ataupun penyebaran masing-masing daerah pada empat kuadran yang tersedia. Kemudian prinsip GIS adalah memperlihatkan secara visual wilayah yang termasuk atau tidak termasuk konsentrasi daerah perhotelan yang ada di kawasan danau Toba berdasarkan kabupaten. 


\section{Analisis Pergeseran Klasifikasi Konsentrasi Daerah Perhotelan}

Tahapan analisis berikut ini dimaksudkan untuk menganalisis apakah ada pergeseran klasifikasi konsentrasi daerah perhotelan di kawasan danau Toba pada periode penelitian (2007-2016) yang berdasarkan pada analisis klasifikasi konsentrasi daerah perhotelan sebagaimana tahap awal di atas. Akan tetapi dalam melihat pergeseran klasifikasi konsentrasi daerah perhotelan tersebut akan di gambarkan dalam scatter plot sehingga akan terlihat perpindahan daerah perhotelan di empat kuadran (konsentrasi utama daerah perhotelan, konsentrasi daerah perhotelan tapi tidak produktif menyerap tenaga kerja, bukan konsentrasi daerah perhotelan tapi produktif menyerap tenaga kerja, dan bukan konsentrasi daerah perhotelan). Sebagai pelengkap, akan di visualisasikan dalam bentuk produk peta awal penelitian tahun 2007 dan akhir penelitan tahun 2016 sehingga jelas terlihat perubahan pada peta kawasan danau Toba tersebut.

\section{HASIL DAN PEMBAHASAN}

\section{Analisis Klasifikasi Konsentrasi Daerah Perhotelan di Kawasan Danau Toba}

Danau Toba sebagai obyek wisata internasional selayaknya dimanfaatkan dengan maksimal oleh tujuh kabupaten yang secara geografis mengelilingi danau Toba dan secara administratif berbatasan langsung dengan danau Toba. Pemanfaatan potensi besar ini sudah seharusnya didukung oleh fasilitas yang memadai seperti penyediaan hotel dan akomodasi lainya. Jika dilihat pada tahun 2007-2016, masing-masing tujuh kabupaten memiliki variasi jumlah unit hotel dan akomodasi lainnya serta jumlah tenaga kerja yang mampu di serap oleh hotel dan akomodasi lainnya. Variasi ini bisa terjadi karena adanya keuntungan lokasi di masing-masing daerah. Jika diklasifikasikan, daerah mana yang merupakan basis dari lokasi perhotelan di kawasan danau Toba? Pertanyaan ini akan dijawab menggunakan scatter plot yang didasarkan pada empat kuadran klasifikasi konsentrasi daerah perhotelan di kawasan danau Toba selama tahun 2007-2016.

Dengan menggunakan SPSS 21 diperoleh scatter plot klasifikasi konsentrasi daerah perhotelan di kawasan danau Toba selama tahun 2007-2016 seperti tampak pada Gambar 1. Rata-rata jumlah unit hotel dan akomodasi lainnya selama periode 2007-2016 sebanyak 35 unit. Sementara rata-rata jumlah tenaga kerja yang diserap oleh hotel dan akomodasi lainnya selama periode 2007-2016 sebanyak 393 orang. Scatter plot terbagi empat 
kuadran. Kuadran I adalah klasifikasi konsentrasi utama daerah perhotelan. Kuadran ini diduduki oleh kabupaten Samosir, kabupaten Karo, dan kabupaten Simalungun. Ini menunjukkan bahwa ketiga kabupaten tersebut memiliki jumlah unit hotel dan akomodasi lainnya di atas 35 unit dan jumlah tenaga kerja yang diserap oleh hotel dan akomodasi lainnya di masing-masing kabupaten tersebut di atas 393 orang. Kuadran II adalah klasifikasi konsentrasi daerah perhotelan tapi tidak produktif menyerap tenaga kerja. Tidak ada daerah atau kabupaten yang menduduki kuadran ini. Artinya bahwa tidak ada kabupaten di kawasan danau Toba yang memiliki jumlah hotel dan akomodasi lainnya di atas 35 unit dan sekaligus menyerap jumlah tenaga kerja hotel dan akomodasi lainnya di masing-masing kabupaten tersebut di bawah 393 orang.

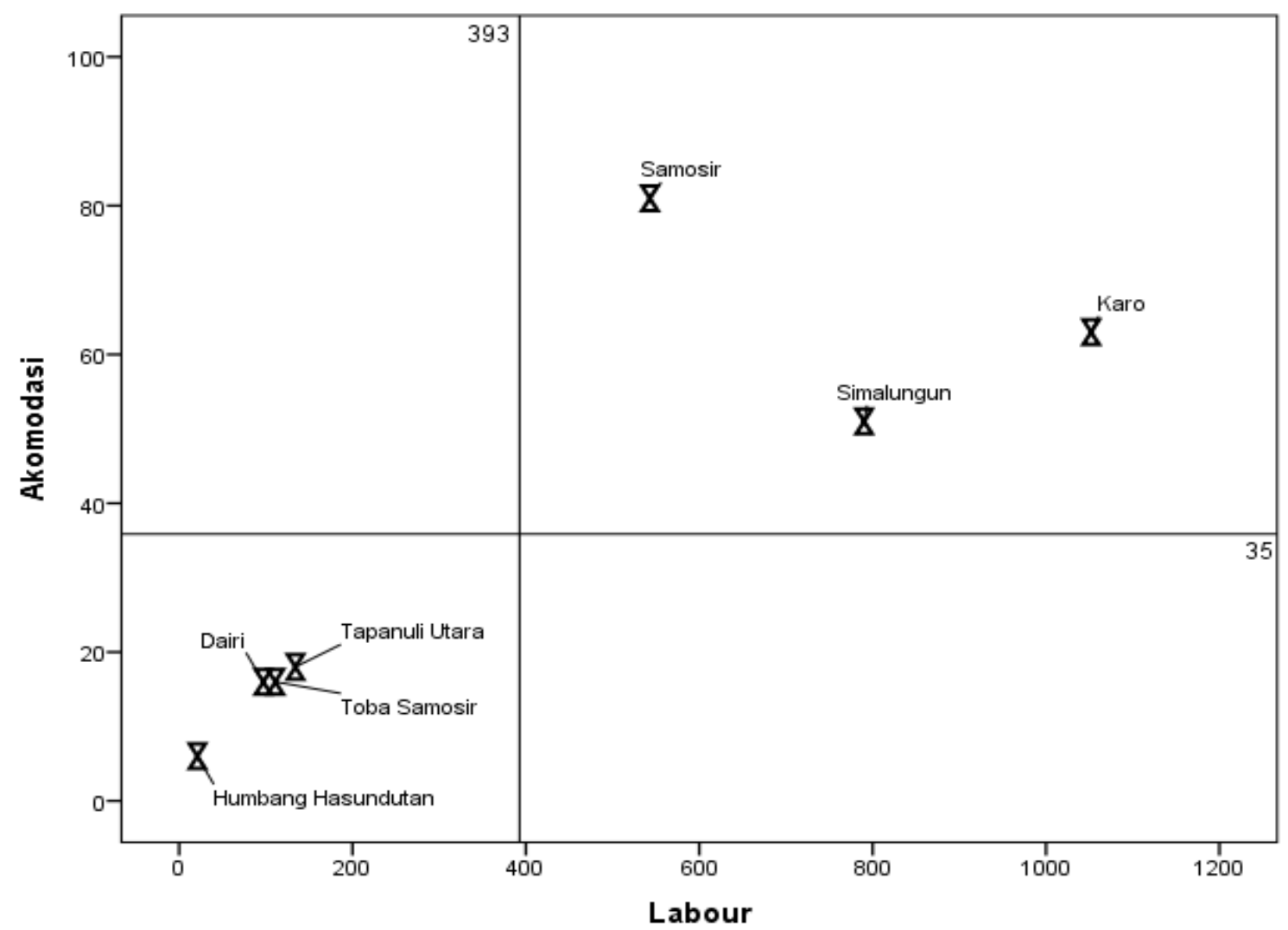

Gambar 1. Scatter Plot Klasifikasi Konsentrasi Daerah Perhotelan Di Kawasan Danau Toba Periode 2007-2016

Sumber: Lampiran B (diolah), 2020

Kuadran III adalah klasifikasi bukan konsentrasi daerah perhotelan tapi produktif menyerap tenaga kerja. Tidak ada daerah atau kabupaten yang menduduki kuadran ini. Artinya bahwa tidak ada kabupaten di kawasan danau Toba yang memiliki jumlah hotel dan akomodasi lainnya di bawah 35 unit dan sekaligus menyerap jumlah tenaga kerja hotel 
dan akomodasi lainnya di masing-masing kabupaten tersebut di atas 393 orang. Kuadran IV adalah klasifikasi bukan konsentrasi daerah perhotelan. Kuadran ini diduduki oleh empat kabupaten di antaranya adalah kabupaten Tapanuli Utara, kabupaten Toba Samosir, kabupaten Dairi, dan kabupaten Humbang Hasundutan. Ini menunjukkan bahwa keempat kabupaten tersebut memiliki jumlah hotel dan akomodasi lainnya di bawah 35 unit dan jumlah tenaga kerja yang diserap oleh hotel dan akomodasi lainnya di masing-masing kabupaten tersebut di bawah 393 orang.

Uraian di atas menunjukkan bahwa terdapat dua klasifikasi daerah perhotelan di kawasan danau Toba selama periode 2007-2016. Kedua klasifikasi tersebut adalah (1) klasifikasi konsentrasi utama daerah perhotelan dan (2) klasifikasi bukan konsentrasi daerah perhotelan. Langkah berikutnya adalah memvisualisasikan daerah masing-masing klasifikasi tersebut ke dalam sebuah produk peta kawasan danau Toba sehingga terlihat jelas kabupaten mana saja yang masuk ke dalam masing-masing klasifikasi yang dimaksud.

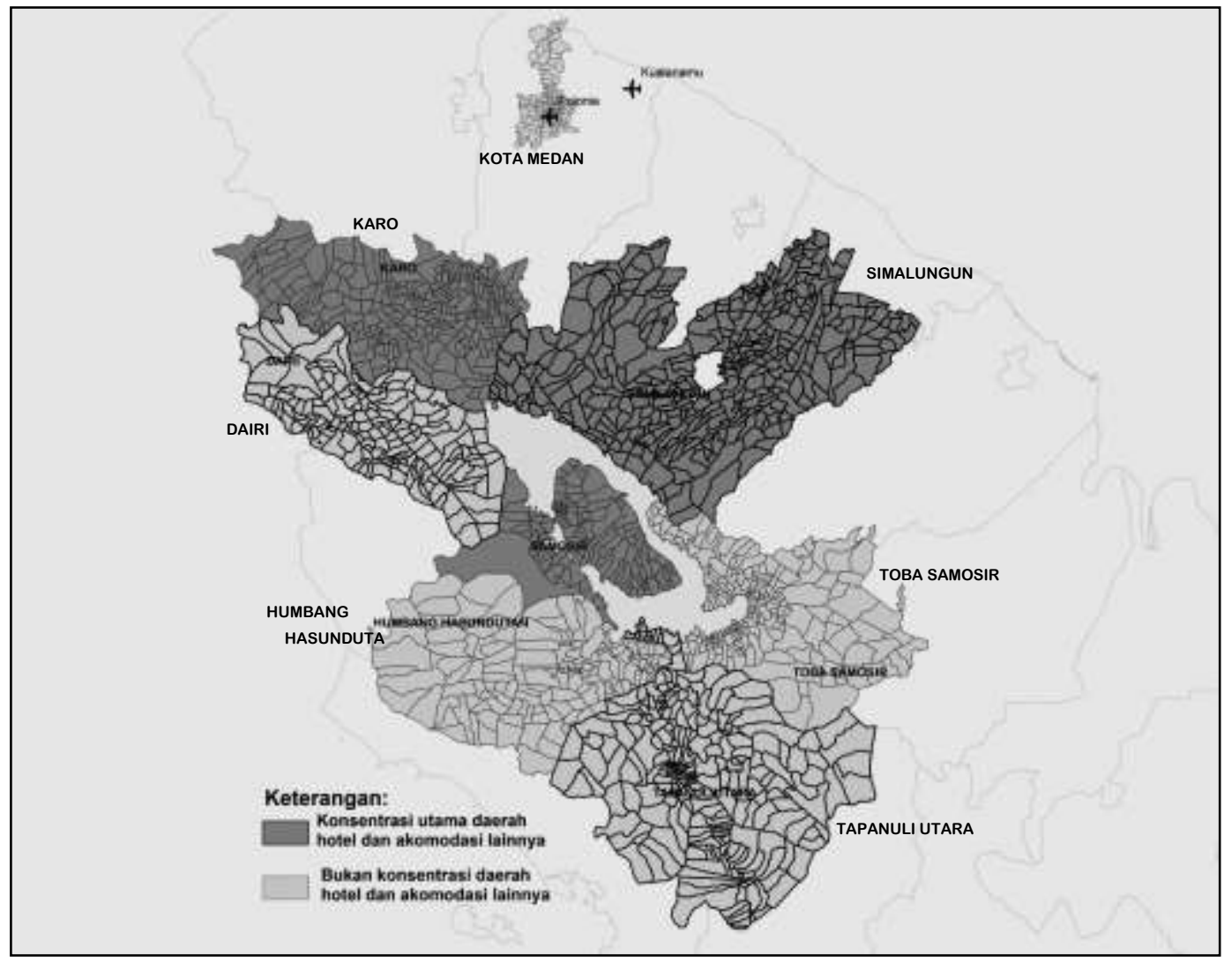

Gambar 2. Peta Klasifikasi Konsentrasi Daerah Perhotelan Di Kawasan Danau Toba Periode 2007-2016

Sumber: Lampiran B (diolah), 2020 
Daerah yang berwarna lebih gelap pada Gambar 2 adalah kabupaten yang masuk dalam klasifikasi konsentrasi utama daerah perhotelan di kawasan danau Toba pada periode 2007-2016. Kabupaten tersebut terkonsentrasi dari utara sampai ke timur danau Toba dan di tengah (daerah pusat) danau Toba itu sendiri. Dua kabupaten yang berada di sepanjang utara-timur danau Toba adalah kabupaten Karo dan kabupaten Simalungun. Sedangkan kabupaten yang berada di tengah danau Toba adalah kabupaten Samosir. Lokasi kabupaten Karo dan kabupaten Simalungun sangat strategis karena lebih dekat pada sumber kedatangan (bandar udara internasional Polonia dan Kualanamu) dan lebih dekat ke ibukota provinsi yakni kota Medan. Sementara lokasi kabupaten Samosir juga sangat strategis karena berada di tengah-tengah danau Toba selaku obyek wisata. Lokasi strategis ketiga kabupaten di atas sesuai dengan yang dikemukakan oleh Muta'ali (2015), dan Luo dan Yang (2016).

Daerah yang berwarna lebih terang pada Gambar 2 adalah kabupaten yang masuk dalam klasifikasi bukan konsentrasi daerah perhotelan di kawasan danau Toba pada periode 2007-2016. Kabupaten tersebut tersebar dari tenggara sampai ke barat laut danau Toba. Empat kabupaten yang berada di sepanjang tenggara sampai ke barat laut danau Toba adalah kabupaten Toba Samosir, kabupaten Tapanuli Utara, Kabupaten Dairi, dan kabupaten Humbang Hasundutan.

\section{Analisis Pergeseran Konsentrasi Daerah Perhotelan di Kawasan Danau Toba}

Jumlah hotel dan akomodasi lainnya di kawasan danau Toba sebanyak 241 unit pada tahun 2007. Sementara jumlah tenaga kerja yang bekerja pada hotel dan akomodasi lainnya sebanyak 2.354 orang. Kemudian pada tahun 2016, jumlah hotel dan akomodasi lainnya maupun jumlah tenaga kerja yang bekerja pada hotel dan akomodasi lainnya masingmasing meningkat sebanyak 290 unit dan 3.085 orang atau setara dengan 20,6 persen dan 31,1 persen. Meningkatnya jumlah unit hotel dan akomodasi lainnya dan jumlah tenaga kerja yang diserap oleh hotel dan akomodasi lainnya di akhir periode penelitian mengisyaratkan adanya kemungkinan pergeseran konsentrasi daerah perhotelan di kawasan danau Toba. Berbeda hal yang terjadi jika ditelusuri pada masing-masing kabupaten. Pada akhir periode penelitian ditemukan adanya kabupaten yang mengalami penurunan jumlah unit hotel dan akomodasi lainnya dan jumlah tenaga kerja yang diserap oleh hotel dan akomodasi lainnya tersebut. Untuk menjawab kemungkinan terjadi atau 
tidak terjadi pergeseran konsentrasi daerah perhotelan di kawasan danau Toba selama periode penelitian maka akan dianalisis menggunakan scatter plot pada awal dan akhir tahun penelitian, dan akan divisualisasikan produk peta awal dan akhir tahun penelitian juga.

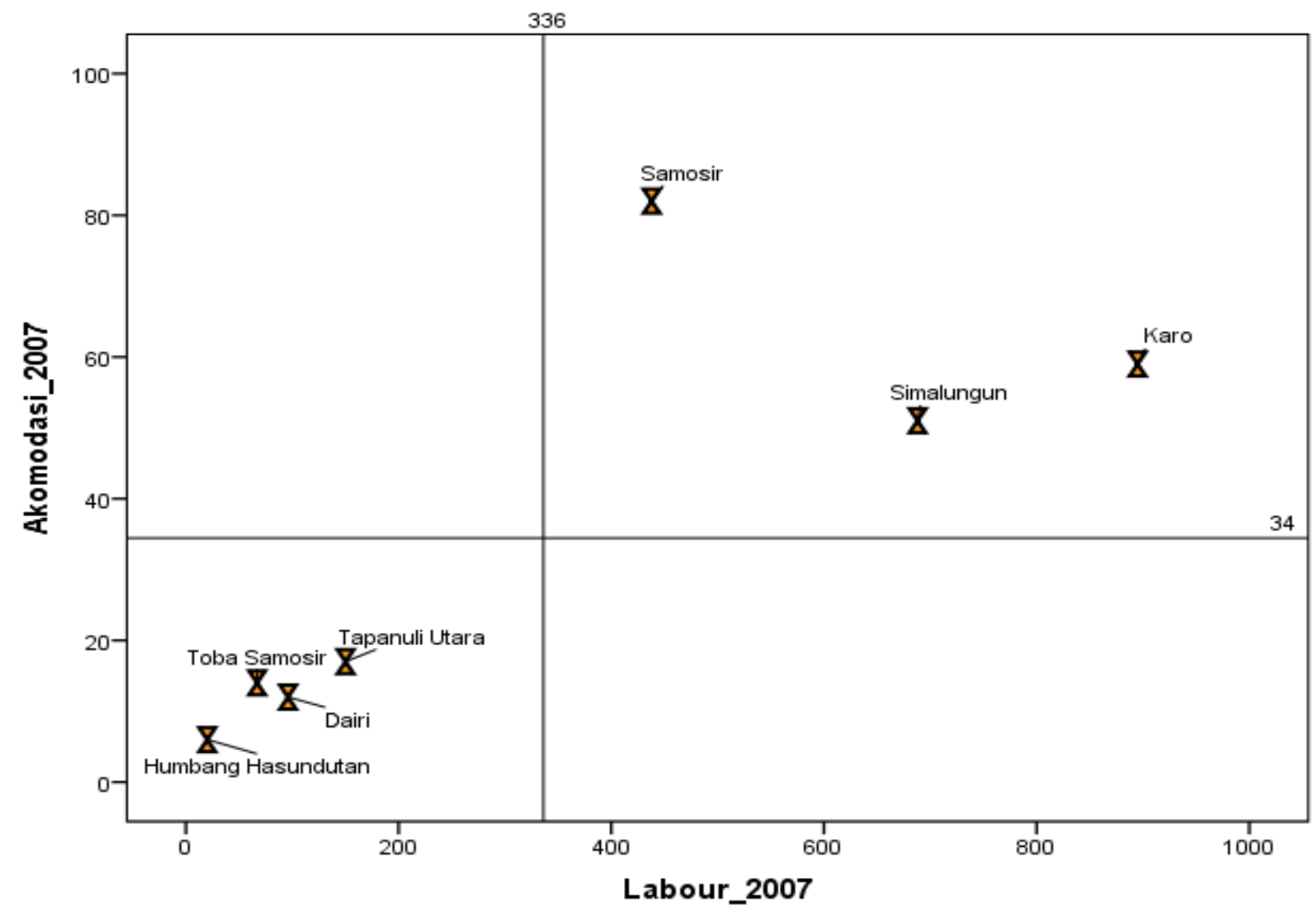

Gambar 3. Klasifikasi Konsentrasi Daerah Perhotelan Di Kawasan Danau Toba Tahun 2007

Sumber: Lampiran B (diolah), 2020

Gambar 3 adalah scatter plot pada awal penelitan tahun 2007. Terlihat jelas pada garis horizontal bahwa rata-rata jumlah hotel dan akomodasi lainnya di kawasan danau Toba sebanyak 34 unit. Sementara garis vertikal menunjukkan bahwa rata-rata jumlah tenaga kerja yang mampu diserap oleh hotel dan akomodasi lainnya di kawasan danau Toba sebanyak 336 orang. Gambar 3 menunjukkan bahwa tujuh kabupaten di kawasan danau Toba tersebar pada dua kuadran dan mengindikasikan bahwa ketujuh kabupaten tersebar di dua klasifikasi pada awal penelitian. Kabupaten Koro, kabupaten Samosir, dan kabupaten Simalungun masuk pada klasifikasi konsentrasi utama daerah perhotelan (lihat kuadran I) karena memiliki jumlah unit hotel dan akomodasi lainnya di atas 34 unit dan jumlah tenaga kerja yang diserap oleh hotel dan akomodasi lainnya pada masing-masing kabupaten tersebut di atas 336 orang. Sementara kabupaten Dairi, kabupaten Humbang 
Hasundutan, kabupaten Tapanuli Utara, dan kabupaten Toba Samosir masuk pada klasifikasi bukan konsentrasi daerah perhotelan (lihat kuadran IV) karena memiliki jumlah unit hotel dan akomodasi lainnya di bawah 34 unit dan jumlah tenaga kerja yang diserap oleh hotel dan akomodasi lainnya pada masing-masing kabupaten tersebut di bawah 336 orang.

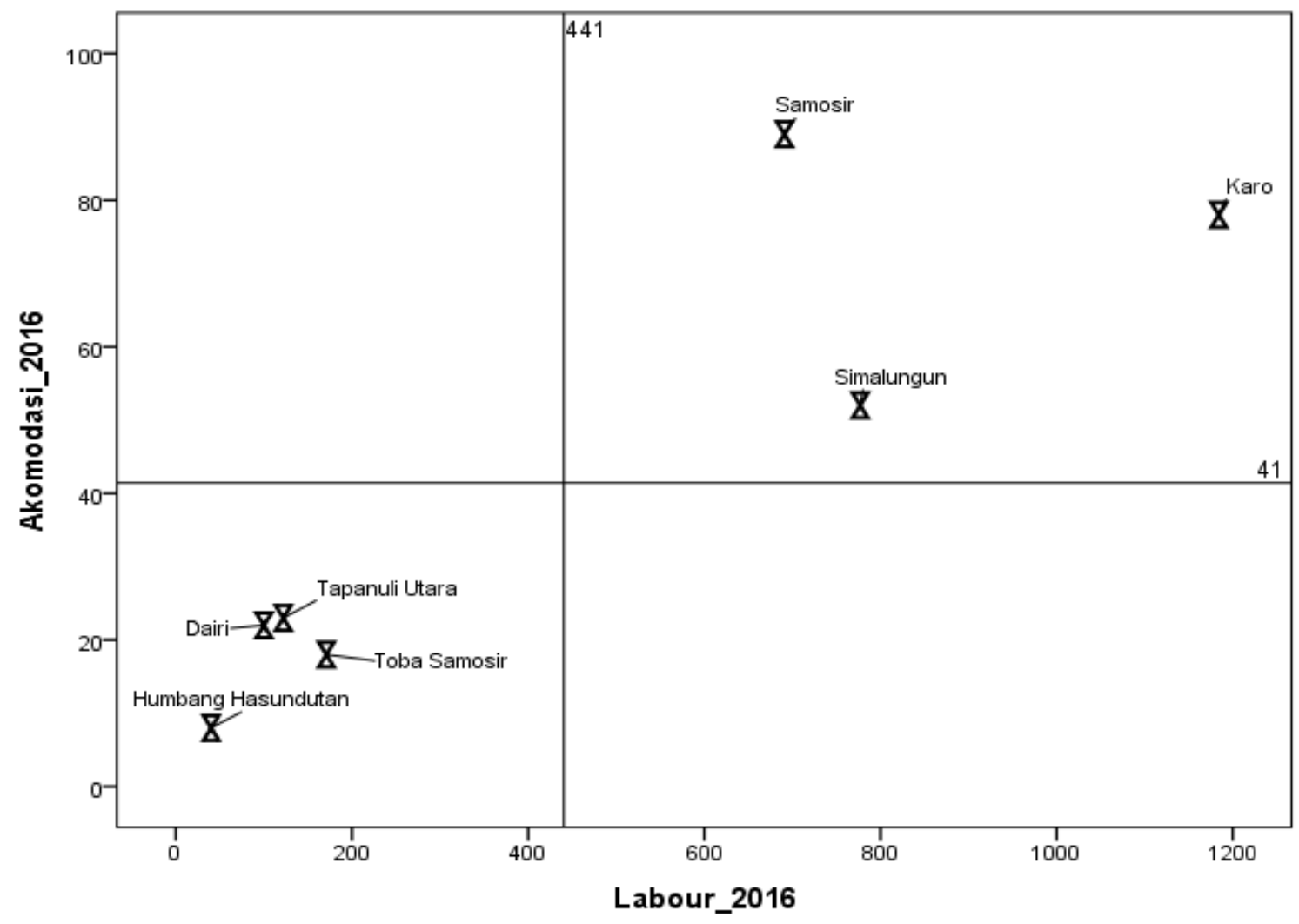

Gambar 4. Klasifikasi Konsentrasi Daerah Perhotelan Di Kawasan Danau Toba Tahun 2016

Sumber: Lampiran B (diolah), 2020

Selanjutnya Gambar 4 adalah scatter plot pada akhir penelitan tahun 2016. Terlihat jelas pada garis horizontal bahwa rata-rata jumlah hotel dan akomodasi lainnya di kawasan danau Toba sebanyak 41 unit. Sementara garis vertikal menunjukkan bahwa rata-rata jumlah tenaga kerja yang mampu diserap oleh hotel dan akomodasi lainnya di kawasan danau Toba sebanyak 441 orang. Gambar 4 menunjukkan bahwa tujuh kabupaten di kawasan danau Toba masih tersebar pada dua kuadran saja dan mengindikasikan bahwa ketujuh kabupaten tetap tersebar di dua klasifikasi pada akhir penelitian. Ketujuh kabupaten hanya mengalami pergerakan pada klasifikasi masing-masing tapi tidak mengalami pergeseran klasifikasi. Pergerakan masing-masing kabupaten pada kuadran masing-masing karena adanya perubahan jumlah unit hotel dan akomodasi lainnya dan 
perubahan jumlah tenaga kerja yang diserap oleh hotel dan akomodasi lainnya. Kabupaten Koro, kabupaten Samosir, dan kabupaten Simalungun tetap masuk pada klasifikasi konsentrasi utama daerah perhotelan (lihat kuadran I) karena memiliki jumlah unit hotel dan akomodasi lainnya di atas 41 unit dan jumlah tenaga kerja yang diserap oleh hotel dan akomodasi lainnya pada masing-masing kabupaten tersebut di atas 441 orang. Sementara kabupaten Dairi, kabupaten Humbang Hasundutan, kabupaten Tapanuli Utara, dan kabupaten Toba Samosir tetap juga masuk pada klasifikasi bukan konsentrasi daerah perhotelan (lihat kuadran IV) karena memiliki jumlah unit hotel dan akomodasi lainnya di bawah 41 unit dan jumlah tenaga kerja yang diserap oleh hotel dan akomodasi lainnya pada masing-masing kabupaten tersebut di di bawah 441 orang.

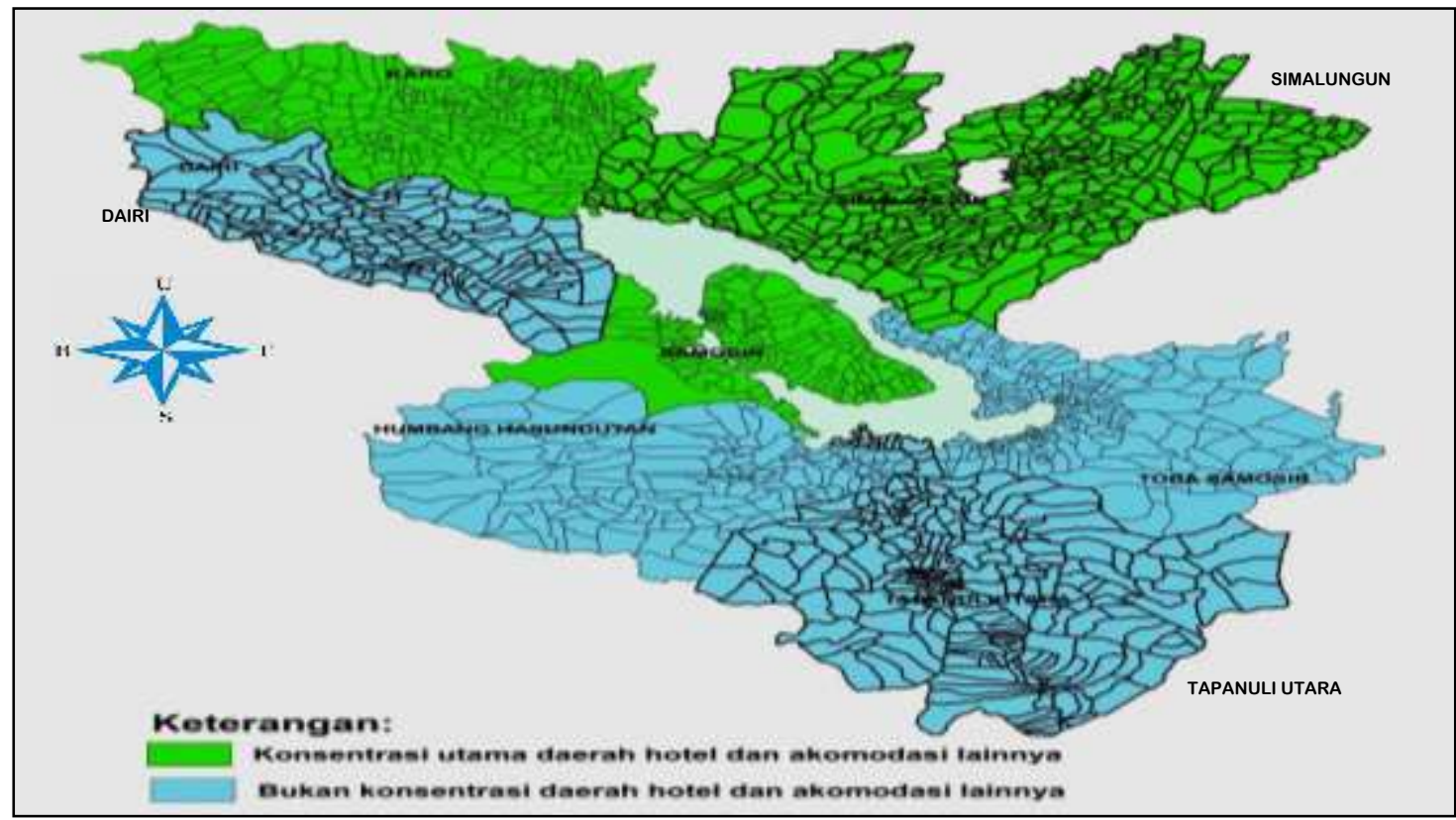

Gambar 5. Peta Klasifikasi Konsentrasi Daerah Perhotelan Di Kawasan Danau Toba Tahun 2007

Sumber: Lampiran B (diolah), 2020

Gambar 5 merupakan visualisasi berbentuk peta tujuh kabupaten yang terbagi pada dua klasifikasi. Peta ini dipakai sebagai pendukung dan penegas scattar plot pada Gambar 3 di atas. Warna hijau merupakan kabupaten yang masuk pada klasifikasi konsentrasi utama daerah perhotelan di kawasan danau Toba. Ada tiga kabupaten pada klasifikasi ini yaitu kabupaten Koro, kabupaten Samosir, dan kabupaten Simalungun. Dua kabupaten (kabupaten Koro dan kabupaten Simalungun) berada di sepanjang utara sampai timur danau Toba dan satu kabupaten (kabupaten Samosir ) di daerah pusat danau Toba tersebut. 
Sementara warna biru merupakan kabupaten yang masuk pada klasifikasi bukan konsentrasi daerah perhotelan di kawasan danau Toba. Ada empat kabupaten pada klasifikasi ini yaitu kabupaten Dairi, kabupaten Humbang Hasundutan, kabupaten Tapanuli Utara, dan kabupaten Toba Samosir. Keempat kabupaten berada di sepanjang timur sampai barat laut danau Toba.

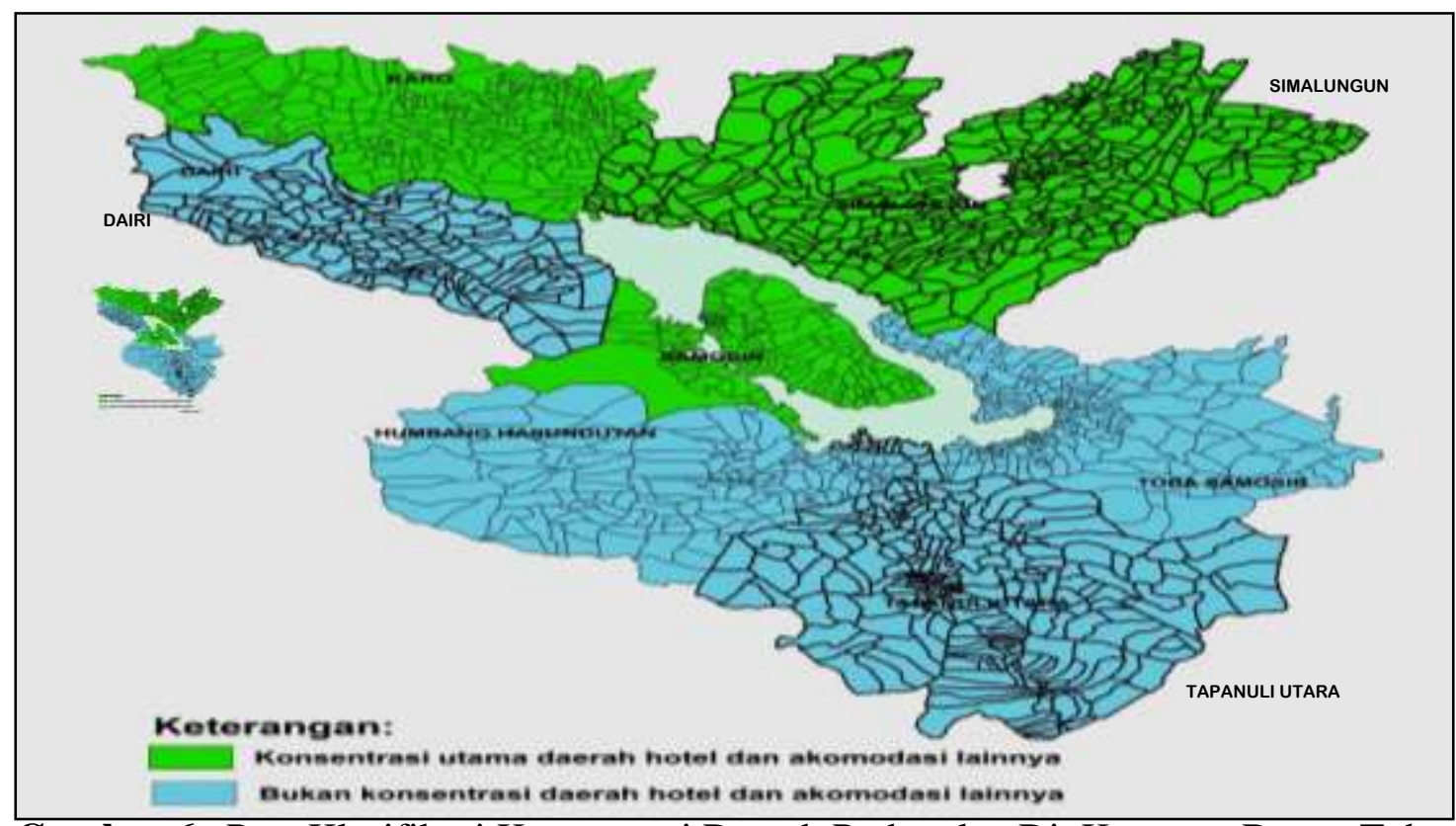

Gambar 6. Peta Klasifikasi Konsentrasi Daerah Perhotelan Di Kawasan Danau Toba Tahun 2016

Sumber: Lampiran B (diolah), 2020

Terakhir adalah gambar 6 merupakan visualisasi berbentuk peta tujuh kabupaten yang terbagi pada dua klasifikasi di akhir periode penelitian. Peta ini digunakan sebagai pendukung dan penegas scattar plot pada Gambar 4 di atas. Warna peta yang dihasilkan pada akhir periode penelitian sama persis dengan warna peta yang dihasilkan pada awal periode penelitian. Artinya bahwa kabupaten yang masuk pada klasifikasi konsentrasi utama daerah perhotelan dan klasifikasi bukan konsentrasi daerah perhotelan di kawasan danau Toba sama saja di awal dan di akhir periode penelitian.

\section{KESIMPULAN DAN SARAN}

Pada periode 2007-2016 kawasan danau Toba dibagi dua klasifikasi yaitu klasifikasi konsentrasi utama daerah perhotelan yakni kabupaten Karo, kabupaten Simalungun, dan kabupaten Samosir, dan klasifikasi bukan konsentrasi daerah perhotelan yakni kabupaten Dairi, kabupaten Humbang Hasundutan, kabupaten Tapanuli Utara, dan kabupaten Toba 
Samosir. Kabupaten yang masuk pada klasifikasi konsentrasi utama daerah perhotelan adalah kabupaten yang dekat dengan bandara internasional, dekat dengan ibukota provinsi, dan dekat dengan obyek wisata. Tidak ada pergeseran klasifikasi konsentrasi daerah perhotelan di kawasan danau Toba selama periode penelitian. Akan tetapi yang ada adalah pergerakan posisi kabupaten di masing-masing kuadran/klasifikasi. Pariwisata danau Toba selaku pariwisata internasional seyogyanya didukung sumber daya manusia yang memadai. Oleh karena itu diharapkan adanya program peningkatan kualitas manusia kepada masyarakat sekitar pada umumnya dan kepada tenaga kerja perhotelan serta pedagang pada khususnya seperti pelatihan bahasa Inggris dan bahasa asing lainnya.

\section{KETERBATASAN DAN REKOMENDASI}

Penelitian ini masih dihadapi keterbatasan berupa tidak tersedianya data tenaga kerja pada hotel dan akomodasi lainya tahun 2017-2019 sehingga informasi yang diperoleh dari penelitian ini kurang update. Penelitian lebih lanjut sangat dibutuhkan untuk memperoleh ilmu dan informasi yang lebih terkait konsentrasi daerah perhotelan. Penelitian yang dimaksud adalah seperti faktor yang mempengaruhi klasifikasi konsentrasi daerah perhotelan di kawasan danau Toba. Kabupaten yang masih berada pada klasifikasi bukan konsentrasi daerah perhotelan sebaiknya meningkatkan pembangunan dan perbaikan tempat wisata supaya para investor tertarik mendirikan hotel dan akomodasi lainnya di daerah tersebut. Sementara kabupaten yang berada pada klasifikasi konsentrasi utama daerah perhotelan tetap mempertahankan atau bahkan meningkatkan pariwisata di daerah tersebut.

\section{DAFTAR PUSTAKA}

Arsyad, Lincolin. (2016). Pengantar Perencanaan Ekonomi Pembangunan Ekonomi Daerah. Edisi Ketiga. Yogyakarta: BPFE.

Badan Pusat Statistik. (2017). Statistik Indonesia: Statistical yearbook of Indonesia 2017. Jakarta: Badan Pusat Statistik.

Badan Pusat Statistik. (2012). Statistik Hotel dan Akomodasi Lainnya di Sumatera Utara 2011. Medan: Badan Pusat Statistik Provinsi Sumatera Utara.

Badan Pusat Statistik. (2016). Statistik Hotel dan Akomodasi Lainnya di Sumatera Utara 2015. Medan: Badan Pusat Statistik Provinsi Sumatera Utara.

Badan Pusat Statistik. (2019). Statistik Hotel dan Akomodasi Lainnya di Sumatera Utara 2018. Medan: Badan Pusat Statistik Provinsi Sumatera Utara. 
Kementerian Pekerjaan Umum dan Perumahan Rakyat (Kementerian PUPR). (2016).

Pada

09

September

2017.

http://www.pu.go.id/uploads/services/infopublik20160330174236.pdf

Kuncoro, Mudrajad. (2015). Mudah Memahami dan Menganalisis Indikator Ekonomi. Yogyakarta: UPP STIM YKPN.

Luo, Hao., \& Yang, Yang. (2016). Intra-Metropolitan Location Choice of Star-Rated and Non-Rated Budget Hotels: The Role of Agglomeration Economies. International Journal of Hospitality Management. 59: 72-83.

Muta'ali, Lutfi. (2015). Teknik Analisis Regional: Untuk Perencanaan Wilayah, Tata Ruang, dan Lingkungan. Yogyakarta: BPFG UGM.

Raharjo, Beni., Ikhsan, Muhamad. (2015). Belajar ArcGIS Desktop 10: ArcGIS 10.2/10.3. Kalimantan Selatan: Geosiana Press. 